\title{
Relating climatological forcing to coastal water levels in Louisiana estuaries and the potential importance of El Niño-Southern Oscillation events
}

\author{
Daniel L. Childers ${ }^{1, *}$, John W. Day, $\mathrm{Jr}^{1}{ }^{\text {, Robert A. Muller }}{ }^{2}$ \\ ${ }^{1}$ Coastal Ecology Institute, Center for Wetland Resources; ${ }^{2}$ Louisiana Office of State Climatology, \\ Louisiana State University, Baton Rouge, Louisiana 70803, USA
}

\begin{abstract}
Between summer 1987 and winter 1988, coastal water levels and marsh inundation regimes in the Mississippi River Deltaic Plain of Louisiana (USA) were anomalously low. This period of low water levels corresponded with the 1987-88 La Nina event, and we hypothesized that the low estuarine water levels were a local manifestation of large-scale climatological forcing related to this unusual event. We used 25 yr (1963 to 1988) of hydrological, climatological, and biological data to investigate this possible relationship between El Niño-Southern Oscillation (ENSO) and La Nina events and water levels in Louisiana estuaries. Records of continuous water levels at brackish and saline marsh sites in the Barataria Basin estuary, Louisiana, from 1987 to 1989 showed the extended period of low marsh inundation. We used a 25 yr water level record (1963 to 1988) from a nearby gauge to ascertain the historical frequency of this type of phenomenon. Our site-specific marsh flooding data were correlated with corresponding 1987-88 water levels from this long-term data set, confirming that historical water level data adequately represented historical marsh inundation. Water levels in Louisiana's microtidal estuaries are closely tied to climatological forcing, and multivariate analysis indicated that wind direction, local precipitation and temperature, and Mississippi River discharge together significantly explained $37 \%$ of the intermonthly variability and $46 \%$ of the interannual variability in our 25 yr coastal water level and marsh inundation record. Coastal water levels explained a small but significant portion $\left(\mathrm{r}^{2}=0.26\right.$ ) of the observed interannual variability (1963 to 1988) in inshore harvest of shrimp - a fishery dependent on seasonal access to estuarine marshes. The relationship between water levels (marsh inundation) and shrimp harvest was curvilinear: shrimp catches were low at both low and high coastal water levels while highest shrimp productivity occurred in years with intermediate water levels. Lowest shrimp catches generally coincided with ENSO and La Niña events. The 1987-88 La Niña event, for example, coincided with an anomalously low marsh inundation regime that functionally isolated marshes from the estuarine water column for long periods. This event may have thus negatively impacted shrimp harvests by denying juveniles access to intertidal marsh habitat. When ENSO events coincided with anomalously high marsh inundation regimes, high water levels were generally associated with high rates of local precipitation and Mississippi River discharges. Although marshes were accessible during these events, spatial reduction of higher salinity waters by large fresh water inputs may have decreased juvenile shrimp habitat and thus contributed to reduced shrimp harvests. In conclusion, we found that climatological forcing has direct effects on estuarine flooding regimes and consequently affects inshore shrimp harvests in coastal Louisiana. Furthermore, the nonlinear relationship between shrimp catch and water level is a result of low-catch endpoints that often correspond to ENSO and La Niña events
\end{abstract}

\section{INTRODUCTION}

Apparent randomness in biological patterns is often related to physical forcing by one or more environ-

\footnotetext{
- Present address: Baruch Institute for Marine Biology and Coastal Research, PO Box 1630, Georgetown, South Carolina 29442, USA
}

mental parameters (Legendre \& Demers 1984). In estuarine systems, coastal water levels and associated wetland inundation regimes together form an important hydrologic control on ecosystem processes (Odum 1980, many others). This is particularly true in flat, expansive, microtidal estuaries, such as those of the Mississippi River Deltaic Plain of Louisiana, USA. Water level patterns in these estuaries are strongly 
influenced by various climatological parameters on both short (days to a week) and intermediate (months to a year) time scales (Conner \& Day 1987, Turner 1987).

Between summer 1987 and winter 1988, coastal water levels in Louisiana estuaries were anomalously low. The result was a dramatic decrease in the marshopen estuary interactions mediated by intertidal flooding. We examined environmental factors which were potentially responsible for the low water levels and what effect this period of reduced marsh inundation had on the estuarine ecosystem. This low water event occurred during the 1988 North American drought which was recently linked to the 1987-88 La Niña event (Kerr 1988, Trenberth et al. 1988). Global climatological events such as El Niño-Southern Oscillation (ENSO) events and related La Niña events may have direct effects on water levels and flooding regimes in Louisiana estuaries through local meteorological forcing. The consequent changes in marsh inundation regimes should be manifested in measures of estuarine productivity such as inshore landings of penaeid shrimp - a marsh-dependent fishery.

\section{Ecological importance of marsh inundation}

There are important interactions between intertidal marshes and associated estuarine waters. A number of recent studies have directly quantified exchanges of nutrients and materials between the water column and salt marshes (Lee 1979, Wolaver et al. 1980, Wolaver \& Zieman 1983a, b, Chalmers et al. 1985, Chrzanowski \& Spurrier 1987, Wolaver \& Spurrier 1988a, b, Childers 1989, Whiting et al. 1989, Childers \& Day 1990a, b) as well as tidal freshwater marshes (Bowden 1986, McIvor \& Odum 1986). While these studies generated a wide range of results regarding the magnitude and direction of net exchanges of carbon, nitrogen, phosphorus, sediments, and biomass, all concluded that marsh-water column exchange processes are important components of estuarine nutrient dynamics and energetics. In fact, Morris et al. (1990) reported a strong positive correlation between Spartina alterniflora production in a South Carolina salt marsh and anomalies in mean sea level during the growing season. When low water levels reduce marsh inundation, marsh-water column interactions are curtailed. If anomalously low water levels persist for long periods of time, the functional isolation of marsh from open water may have a pronounced effect on the estuarine ecosystem.

The intertidal marsh is also an important habitat for estuarine fish and invertebrates, many of which form the basis for commercially exploitable fisheries. Tidal freshwater marsh fish, for example, preferentially utilize the shallow habitats which fringe marsh edges at low tide and quickly seek shelter on the marsh surface as water levels increase on the flooding tide (McIvor \& Odum 1988). Boesch \& Turner (1984) found a high correlation between inshore shrimp yields and area of vegetated marsh in estuaries of the northern Gulf of Mexico. Commerical landings of shrimp and menhaden from the southeastern Atlantic coast of the USA and northern Gulf of Mexico have been positively correlated with sea level anomalies (Morris et al. 1990). In a Texas salt marsh, densities of juvenile brown shrimp Penaeus aztecus in non-winter months were significantly higher in Spartina alterniflora marshes than in adjacent tidal creeks (Zimmerman \& Minello 1984). The vegetated wetland serves as both a refuge against predators and a source of nutrition to these animals (Boesch \& Turner 1984, many others).

Zimmerman \& Minello (1984) noted a close relationship between brown shrimp densities in Texas salt marshes and seasons with high water levels. They hypothesized that exploitation of vegetated habitat may improve crucial estuarine nursery functions and that the timing of higher water levels may determine the ability of brown shrimp to use a marsh. Clearly, reduced frequency and duration of marsh flooding will curtail the use of marsh habitat, by juvenile and estuarine fish and invertebrates, for refuge and feeding. If low water conditions persist through months crucial to a species' juvenile development, the result may well be seen in a reduced year class of organisms. Postlarval brown shrimp begin migrating into Louisiana estuaries in late winter, and remain until early summer. White shrimp Penaeus setiferus follow a similar life cycle but reside in estuaries from early summer through mid-fall (Thompson \& Forman 1987). Thus, non-winter marsh flooding regimes are most critical to the commercially important shrimp species of Gulf Coast estuaries.

\section{Coastal water levels and Louisiana marsh inundation regimes}

Estuarine water levels vary over a number of hierarchical time scales, from periods of hours to decades. The importance of longer term sea level variability to inundation-moderated interactions between marshes and estuaries has been recognized for some time (Kjerfve et al. 1978). In this century, coastal water levels along the northern Gulf of Mexico have shown a 20 yr long-term cyclic pattern around a long-term apparent sea level rise of ca $1 \mathrm{~cm} \mathrm{yr}^{-1}$ Apparent sea level rise from 1942 to 1962 was greater than from 1962 to 1982 , for example (Turner 1987). Average monthly water levels on the Louisiana coast vary seasonally by ca 25 $\mathrm{cm}$ and mean marsh flooding regimes closely follow 
this seasonality (Baumann 1987). Lowest water levels and minimal inundation occur in the winter, when coastal salt marshes are flooded an average of 25 to $40 \%$ of the time, and maximal water levels and inundation occur in early summer and early fall, when salt marshes are flooded up to $80 \%$ of the time. A secondary low seen in midsummer and a secondary high in the spring complete the characteristic bimodal annual pattern observed along the Louisiana coast (Baumann 1987). Astronomical tides and winds control hourly and daily water level fluctuations in Louisiana estuaries (Wax 1977, Conner \& Day 1987).

\section{Climatological forcing and Louisiana marsh inundation regimes}

Variability in water levels on the Louisiana coast is often related to large-scale atmospheric phenomena occurring either local to or distant from coastal environments. In coastal Louisiana, local precipitation and runoff significantly impact estuarine water levels, marsh inundation regimes, and salinities (Baumann 1987). In addition, water levels and salinities are affected by runoff from river basins draining into the coastal wetlands and especially by the discharge of the Mississippi River system - representing runoff from $41 \%$ of the contiguous USA (Muller 1975, Baumann 1987). Hence, excessive runoff from a massive midlatitude cyclone over the upper Midwest can affect water levels, salinities, and water temperatures in Mississippi River deltaic wetlands (Meade \& Emery 1971). In fact, much of the bimodal seasonality in water levels on the Louisiana coast is related to remote climatological forcing. The spring peak in water levels has been related to Mississippi River discharge to the coastal zone (Meade \& Emery 1971) and a lessening of northerly wind stress (Wax 1977) while the fall peak has been related to steric effects (Whitaker 1971, Sturges \& Blaha 1976, Baumann 1987) as well as the return of water, stored during winter and spring as continental soil moisture, to rivers and coastal oceans (Mather 1974).

Astronomical tidal ranges of the Northern Gulf coast average only $32 \mathrm{~cm}$ (Baumann 1980) and wind systems have a strong effect on estuarine water levels in Louisiana (Baumann 1987). Louisiana estuaries are expansive and shallow, and long fetches coupled with minimal topographic resistance further increase the importance of wind forcing. These estuaries are generally oriented along north-south axes; northerly winds tend to lower estuarine water levels and marsh flooding regimes while southerly winds will 'push' Gulf waters into estuaries and raise water levels (Baumann 1980). Wax (1977) related weather patterns associated with regional wind systems over southeastern Louisiana to (forced) fluctuations in estuarine water levels in coastal Louisiana.

\section{El Nin̄o-Southern Oscillation events}

One of the largest interannual fluctuations in the global ocean-atmosphere climatological system is the periodic warming of the eastern South Pacific Ocean, known as the El Niño, and closely related reversal of South Pacific atmospheric pressure centers - the Southern Oscillation (U.S. Climate Research Committee 1983, many others). These closely coupled events, referred to as ENSO events, are natural oscillations in the ocean-atmosphere system that influence weather patterns over much of the globe (Graham \& White 1988, Hamilton 1988). ENSO events have occurred with a long-term irregular frequency of 2 to $7 \mathrm{yr}$ since early in the 16th century (Quinn et al. 1987), but have occurred at a more regular 5 yr interval in the last 40 to 50 yr (Rasmussen \& Carpenter 1982, Graham \& White 1988). Since 1961, there have been 2 moderate ENSO events, in 1965 and 1976, and strong events in 1972-73 and 1982-83 (Quinn et al. 1978, Mysak 1986, Barnett at al. 1988, Cheney \& Miller 1988). Mysak (1986) and Enfield (1987) both present good reviews of the onset and progression of an ENSO event.

In the northern hemisphere, most extratropical responses to ENSO events occur along common modes of low-frequency barotropic variability known as teleconnections (Yarnal 1985, Hamilton 1988). At upper tropospheric heights (ca $500 \mathrm{mb}$ ) these zones of correlated variability often correspond to atmospheric pressure centers. For example, the Pacific-North American teleconnection pattern links the Central Pacific High, the Aleutian Low, and the Canadian High to the southeastern USA (Wallace \& Gutzler 1981). This teleconnection forms an important connection between tropical Pacific pressure center oscillations and USA Gulf Coast weather patterns (Yarnal 1985). Most ENSO-related variability in northern hemispheric climatological conditions occurs in the winter half of the year, when pressure differentials and teleconnections are strongest (Horel \& Wallace 1981, Hamilton 1988). There is generally a 1 to 2 season lag between the fall onset of a typical ENSO event and the wintertime climatological response in the continental USA (Horel \& Wallace 1981).

Strong ENSO events generate several important climatological anomalies in southeastern USA and Gulf Coast weather patterns, including: (1) southerly displacement of the winter jet stream, triggering unusually stormy weather (Chen 1983); (2) strengthening of geostrophic pressure gradients across the Pacific-North American teleconnection (Horel \& Wallace 1981); and (3) increased cloud cover (Angell \& Korshover 1987). In 


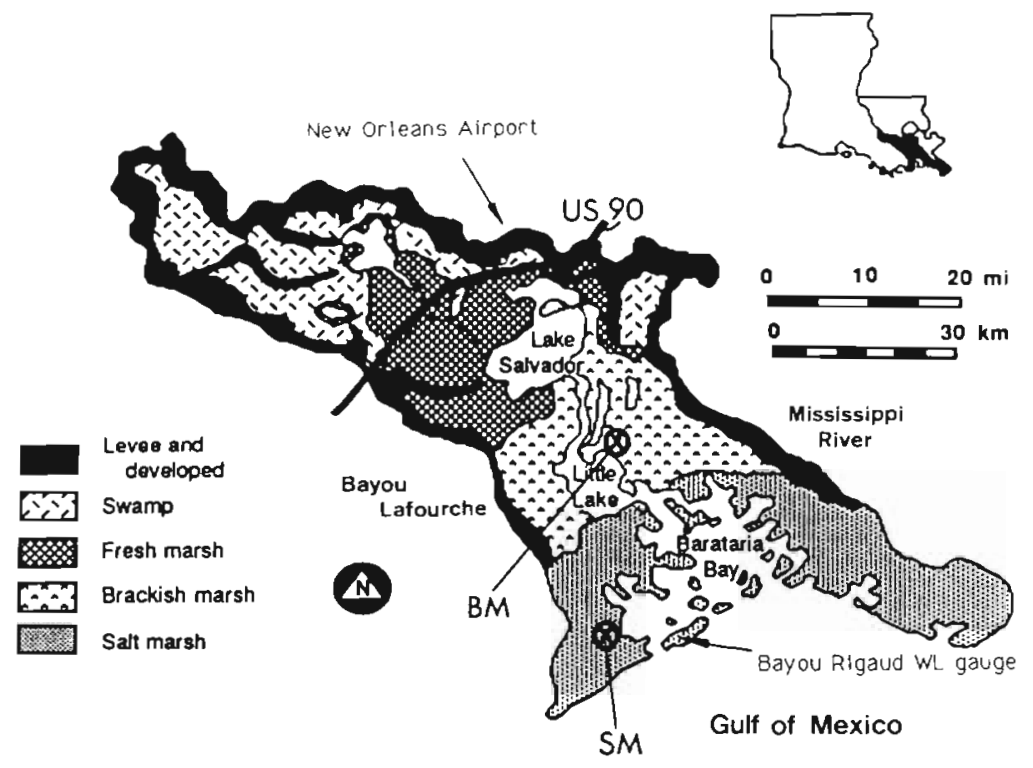

Fig. 1. Barataria Basin estuary, Louisiana, USA, bounded on the east by the Missisippi River levees, on the west by the Bayou Lafourche levees, and on the north by U.S. Highway 90 . X: water level gauge sites: BM, brackish marsh site; $\mathrm{SM}$, saline marsh site. Positions of the New Orleans Airport Meteorological Station and the Bayou Rigaud water level gauge are shown. Note that the estuary is oriented on a southeast-northwest axis from the Gulf of Mexico (modified from Conner \& Day 1987) coastal Louisiana, these anomalies may have direct effects on local climatology In fact, the very strong ENSO event of 1982-83 coincided with massive rains in south Louisiana, extensive local flooding, greater than average discharge from the Mississippi River, and record discharges from several local rivers (Muller \& Faiers 1984).

In mid-1986, a classical appearing ENSO-type event began and reached strength by November-December 1986, remaining strong for about 17 mo (Barnett et al. 1988, Cheney \& Miller 1988). This event was peculiar, however, because of what happenend next: in early 1988, the warming of the eastern tropical Pacific (the El Niño) quickly reversed and waters became anomalously cold (Kerr 1988). This pattern reversal, recently called a 'La Niña' event, also reversed the climatological response in the continental USA and very dry conditions developed across the Midwest and Upper South (Kerr 1988). The 1988 drought appears to be a PacificNorth American teleconnection response to this negative sea surface temperature anomaly in the Tropical Pacific (Trenberth et al. 1988). It was during this La Niña event that low water levels and reduced frequency and duration of marsh flooding were observed in coastal Louisiana. We hypothesized that ENSO events coincided with increased coastal marsh flooding, caused primarily by high precipitation rates, while unusual La Niña events which generated dry conditions coincided with decreased marsh flooding.

\section{MATERIALS AND METHODS}

Water levels were measured from May 1987 to March 1989 at a coastal salt marsh site (SM) and from May 1987 to April 1989 at a brackish marsh site (BM) in the Barataria Basin estuary, Louisiana, using Richardstype water level recorders (Weathertronics, Inc. Model 6510 ). These sites are located ca 10 and $40 \mathrm{~km}$ from the Gulf of Mexico, respectively (Fig. 1). Surveys of the marsh microtopography at each site, relative to each water level recorder datum, allowed us to determine water height at bankful stage. From the continuous water level records, we calculated hours of marsh inundation as a percent of total hours each month.

Coastal water level records were obtained from the U.S. Army Corps of Engineers (U.S.A.C.E.) Bayou Rigaud Gauging Station, on Grand Isle, Louisiana. This gauge, located on the Gulf of Mexico, is ca $15 \mathrm{~km}$ from the salt marsh site described above. Hourly data from January 1963 through May 1988 were averaged by month to smooth astronomical tidal variability. Apparent sea level rise $\left(1.4 \mathrm{~cm} \mathrm{yr}^{-1}\right)$ was removed from this water level record by regressing the $25 \mathrm{yr}$ monthly mean time series against time and filtering the resultant slope from the data set. Annual mean water levels are averages of monthly means. Both monthly and annual means were compared to the overall 25 yr mean to determine positive and negative anomalies. We correlated these water level data to the site-specific records of marsh flooding in the Barataria Basin estuary, and looked for past recurrences of the anomalously low flooding regime observed in 1987-88.

A number of climatological parameters from the same time period were also analyzed. Monthly and annual mean temperatures and total precipitation were calculated for 1963 to 1988 from data taken at the New Orleans Moisant Airport (Louisiana Office of State Climatology, Baton Rouge, Louisiana), which is near the northern boundary of the Barataria Basin estuary. Both monthly and annual data were used to lessen error associated with unknown lags from climatological 
forcing to environmental responses. We classified wind data using synoptic climatological indices that categorize weather patterns by similarity of conditions, including winds, pressure gradients, and frontal movements (Muller 1977). In this method, each day is assigned a synoptic weather type based on appraisal of the 06:00 h CST (Central Standard Time) daily weather map and on meterorological observations made every third hour at the New Orleans Moisant Airport (Muller 1977). These data are presented as the percent of total recorded hours per month when each synoptic index type was observed each month (Louisiana Office of State Climatology). In this analysis, we used synoptic weather type calendars (1961 to present) that have been compiled for coastal Louisiana (Muller \& Willis 1983, Louisiana Office of State Climatology, Baton Rouge). The important weather indices were those characterized by winds blowing parallel to the estuarine axis, as this wind stress is most important to water level variability. The Continental Index (CI) represents weather types where northerly winds dominate and the Tropical Index (TI) where southerly winds predominate (Muller \& Wax 1977). CI weather tends to force water from the estuary, lowering water levels, while TI weather forces water into the estuary (Wax 1977, Baumann 1987). We calculated annual means from these monthly percentages. Annual mean discharge of the Mississippi River was calculated from monthly averaged discharge data for 1963 to 1988 at the gauging station at Tarbert Landing, Mississippi (U.S.A.C.E.). This station was chosen because it is upstream of the Louisiana coastal zone and therefore represents river discharge independent of the effects of local precipitation and runoff.

We investigated the relative importance of these various environmental parameters to observed coastal water levels with multivariate analysis, including stepwise and multiple regression techniques (Statview II ${ }^{\circledR}$ statistical package). This multivariate analysis determined which environmental parameters explained the most variability in coastal water level patterns on both monthly and annual time frames. Data for March through October were used for all monthly analyses, as this is when juvenile shrimp utilize marsh habitats in Louisiana estuaries (Thompson \& Forman 1987, others). Bayou Rigaud water level was the dependent variable, and annual precipitation, mean temperature, TI (southerly winds), CI (northerly winds), and Mississippi River discharge were the independent variables. The degree of colinearity of independent variables was tested using Pearson's correlation matrices.

Catch data from the Louisiana shrimp fishery, including pounds landed inshore and effort expended, were obtained from the National Marine Fisheries Service (New Orleans, Louisiana) for 1963 to 1988. The inshore shrimp fishery (primarily brown and white shrimp Penaeus aztecus and $P$. setiferus) was chosen for a number of reasons: (1) historical data were both reliable and available; (2) shrimp utilize the marsh surface and thus depend on access via marsh inundation (Boesch \& Turner 1984, Zimmerman \& Minello 1984); (3) it was possible to look only at estuarine catch, reducing variability related to offshore population dynamics; and (4) shrimp grow quickly, reducing complications related to year classes and long lags in population responses to environmental forcing. We converted inshore shrimp catch values to catch per unit effort (CPUE) by dividing landings by effort (as $\mathrm{kg}$ trip $^{-1}$ ). Louisiana shrimp catch showed a highly significant increase $\left(r^{2}=0.59, p<0.001\right)$ over this time period. To be consistent in the treatment of time series data, this temporal increase in shrimp CPUE was filtered from the data by computing the residual CPUE values from this regression and identifying them as normalized CPUE.

As with the Bayou Rigaud water level data set, we subjected shrimp CPUE and normalized CPUE (dependent variables) to multivariate analysis using Bayou Rigaud water level, precipitation, temperature, CI. TI, and Mississippi River discharge as independent variables. In this case, annual means were calculated using only monthly data for March-October, as with the monthly analyses discussed above. Both normalized and uncorrected CPUE data were offset 1 yr earlier, to simulate a potential $1 \mathrm{yr}$ lag in population response to flooding regime variability. We also analyzed this lagged data set with the multivariate techniques discussed above.

\section{RESULTS AND DISCUSSION}

\section{Marsh inundation regimes}

The inundation regimes at both the brackish (BM) and saline (SM) marsh sites declined dramatically in. July 1987 and remained low through late 1988 (Fig. 2). For comparison, a published 5 yr mean flooding regime for Barataria Basin salt marshes, from 1975-1979 (Baumann 1980), is superimposed over our data in Fig. $2 \mathrm{~b}$ - there is no published average of brackish marsh inundation for comparison with Fig. 2a (C. Sasser, Louisiana State Univ., pers. comm.). At the brackish marsh site, the marsh was inundated less than $10 \%$ of the time from July 1987 through August 1988 (Fig. 2a). In fact, between mid-December 1987 and mid-March 1988 , the marsh at this site failed to flood for 92 consecutive days. At both sites, the 1987-88 marsh inundation regime was anomalously low and the temporal pattern in flooding was markedly attenuated for an extended period of time. 
a

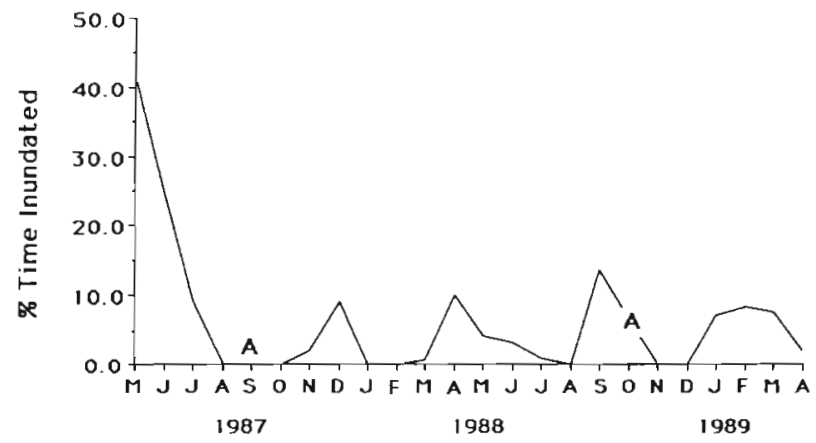

b

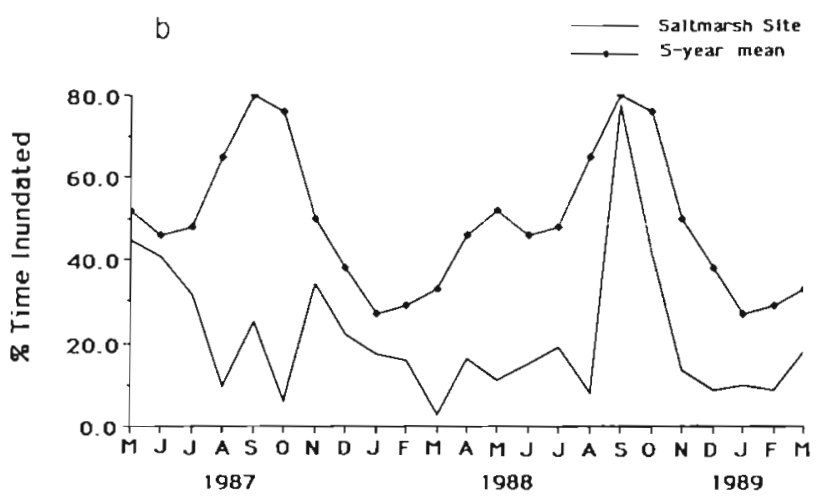

Fig. 2. Flooding regimes measured at (a) brackish and (b) salt marsh sites of the Barataria Basin estuary. In (a), $A=$ no data (gauge down). In (b) the 5 yr average, 1975-1979, is from Baumann (1980)

Barataria Basin salt marshes typically experience 160 high water inundations per year (Madden et al. 1988) compared to as many as 700 in a mesotidal and semidiurnal southeastern USA salt marsh - assuming high water inundations approximately every $12.5 \mathrm{~h}$. The marsh at the SM site flooded 123 times between May and December 1987, 117 times in 1988 (12 mo), and 30 times between January and March 1989. In ecological terms, however, the duration of flooding may be more critical. Comparison of 1987 to 1989 salt marsh flooding frequencies with the 5 yr mean shown in Fig. $2 \mathrm{~b}$ (Baumann 1980) indicated that monthly flooding durations were reduced 32 to $92 \%$ at the SM site. Furthermore, the bimodal seasonal pattern typical of the monthly mean data was nearly completely attenuated, and did not return until late 1988 to early 1989.

\section{Coastal water levels}

Annual means of hourly water level readings at the Bayou Rigaud gauging station on Grand Isle provide a 25 yr picture (January 1963 through May 1988) of Gulf coast water levels at the Barataria Basin estuary. These data showed an apparent sea level rise over the time a

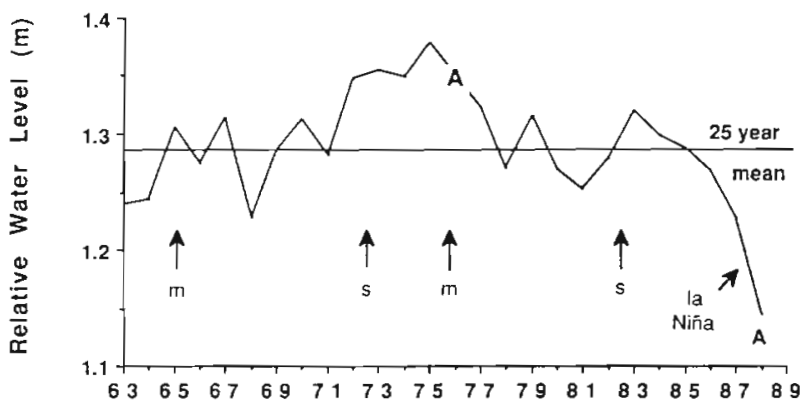

b Bayou Rigaud data Actual WLe25 yr mean

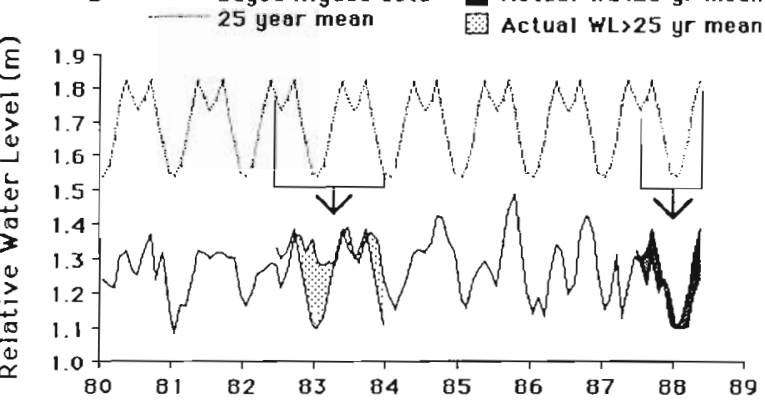

Fig. 3. (a) Filtered annual mean water levels and 25 yr mean from the Bayou Rigaud coastal gauge on Grand Isle, computed from hourly water level readings (U.S.A.C.E.). A incomplete data set (only 3 mo of data were available from 1976,1988 data through May). ENSO and La Niña events are indicated with arrows; s: strong event, m: moderate event. (b) Lower: monthly mean water levels from the same gauge, computed from hourly water level readings (U.S.A.C.E.); upper: $25 y$ average monthly water levels. The 1982-83 and 1987-88 segments of the top panel are superimposed onto the bottom panel; light shaded areas indicate where actual coastal water levels were anomalously high, dark shaded areas indicate where actual coastal water levels were anomalously low (see text)

period analyzed of $1.40 \mathrm{~cm} \mathrm{yr}^{-1}\left(\mathrm{r}^{2}=0.35, \mathrm{p}<0.01\right)$. The temporal pattern with this increase filtered out is shown in Fig. 3a. The low water event in 1987 and 1988 is clearly observable when compared to the 25 yr mean water level. The interannual variability about this mean is also highlighted by a multi-year period of high water levels from 1972 to 1975 .

The monthly percent flooding values at the SM site (Fig. 2b) were significantly correlated $(p=0.04$ ) with mean water levels at Bayou Rigaud for the same months, confirming that the historical Bayou Rigaud water level record is an adequate surrogate for marsh inundation. The 25 yr means of monthly water levels at Bayou Rigaud show a bimodal seasonal pattern with equivalent spring and late summer peaks, a slight summer depression, and low winter values (Fig. 3b, upper curve). Patterns observed in monthly mean water levels from 1980-1988 vary from year to year 
(Fig. 3b, lower curve). Notably, the bimodal seasonal pattern was markedly attenuated in the actual data from mid-1982 to mid-1983 and for all of 1987-88 (lower panel of Fig. 3b with curves superimposed). In 1982-83, water levels were above the 25 yr monthly average and corresponded to a period of high precipitation in coastal Louisiana (Muller \& Faiers 1984). In 1987-88, though, during a period of drought in much of North America, water levels were well below the average (Kerr 1988, Trenberth et al. 1988; see shaded areas, Fig. 3b). These 2 time periods also corresponded with the very strong 1982-83 ENSO event and the recent 1987-88 La Nina event.

\section{Marsh inundation regimes and climatological effects}

The climatological parameters described above each contribute to the intermonthly and interannual variability observed in water levels on the Louisiana coast. Pearson correlation matrices were calculated to assess colinearity in the climatological variables (Table 1). The Continental and Tropical wind indices were strongly intercorrelated, as expected since northerly and southerly winds are mutually exclusive, with correlations of -0.86 (monthly means; Table 1 , left hand column) and -0.90 (annual means; Table 1, top row). Monthly and annual mean wind indices were also somewhat colinear with temperature, because north winds dominate winter weather patterns and colder years while southerly winds are characteristic of the summer and warmer years. Mississippi River discharge was somewhat intercorrelated with temperature on a monthly scale - again because of the seasonal signal and with precipitation on an annual scale. Most other correlations amongst the climatological parameters were comparatively low, indicating a relatively low degree of colinearity (Table 1).

Multivariate analysis of March through October monthly precipitation, temperature, $\mathrm{CI}$ and $\mathrm{TI}$ weather conditions, and Mississippi River discharge to monthly mean water levels at Bayou Rigaud, as a surrogate for

Table 1. Pearsons correlation matrices of monthly (lower left, means for March through October only) and annual (upper right) data for independent variables used in multivariate regression models. Precip: total precipitation; $\mathrm{Cl}$ : Continental Index weather; TI: Tropical Index weather; Temp.: mean temperature; Miss. R. Q.: Mississippi River discharge

\begin{tabular}{|lccccc|}
\hline & Precip. & CI $(\%)$ & TI $(\%)$ & Temp. & Miss. R.Q. \\
\hline Precip. & 1 & -0.058 & 0.012 & 0.206 & 0.354 \\
CI (\%) & -0.234 & 1 & -0.903 & -0.537 & -0.157 \\
TI (\%) & 0.291 & -0.857 & 1 & 0.466 & 0.303 \\
Temp. & 0.167 & -0.545 & 0.69 & 1 & 0.053 \\
Miss. R.Q. & 0.087 & 0.009 & -0.055 & -0.36 & 1 \\
\hline
\end{tabular}

the marsh flooding regime, showed that these 5 climatological indicators explained $37 \%$ of the variability in monthly mean coastal water levels at Bayou Rigaud ( $p<0.001$; Table 2). Temperature had the stongest explanatory capability, as expected with the seasonal pattern of high summer and low winter water levels (Fig. 3b). Southerly winds (TI) and precipitation also contributed significantly $(p \leq 0.05)$ to a nonforced stepwise model. All three had positive relationships with Bayou Rigaud water levels. Coastal water levels increased with increasing temperature, precipitation, and prevalence of southerly winds (Table 2).

A significant $(\mathrm{p}=0.032)$ mutilple regression revealed that $46 \%$ of the variability in mean annual water levels at Bayou Rigaud was explained by these same 5 climatological variables (Table 3). In this analysis of annual data, precipitation had the greatest effect on coastal water levels $\left(r^{2}=0.274\right)$ and both wind indices (CI and TI) explained a considerable percentage of the interannual variability in water levels $\left(r^{2}=0.16\right)$, but Mississippi River discharge and temperature had very little effect $\left(\mathrm{r}^{2}=0.028\right)$. Interestingly, the regression coefficient in the annual model $\left(r^{2}=0.462\right.$; Table 3$)$ was greater than in the monthly model $\left(\mathrm{r}^{2}=0.38\right.$; Table 2). This is probably due to the wide-ranging lags in water level response times to the different climatological parameters. Coastal water levels, for example, respond quickly to wind forcing (hours to a few days) and local precipitation (less than a month; Wax 1977. Baumann 1987) but there is a longer lag between Mississippi River discharge measured inland of the coastal zone and coastal water levels. In fact, while Meade \& Emery (1971) noted that river discharge should have a positive effect on Louisiana Gulf coast water levels on an annual basis, Mississippi River discharge was not a significant factor in multiple regres-

Table 2. Contributions of independent variables (columns) to intermonthly variability observed in Bayou Rigaud water levels using monthly means for March through October. Each $X_{1}$ position indicates the cumulative regression coefficient generated from multiple regression analysis of the model. +: positive slope, - : negative slope. Stepwise order indicates significantly contributing variables as determined by nonforced stepwise regression techniques. Overall $X_{i}$ model $r^{2}$ is shown in the right column; the model $\mathrm{p}$-value was $<0.001$ $(\mathrm{n}=180)$. T: mean annual temperature; TI: Tropical Index weather; P: monthly precipitation; Cl: Continental Index weather; MRQ: Mississippi River discharge

\begin{tabular}{|llllllll|}
\hline Statistic & \multicolumn{8}{c|}{ Independent variables } \\
& T & TI & P & CI & MRQ & Total \\
\hline r-square & 0.241 & 0.318 & 0.357 & 0.365 & 0.365 & 0.365 \\
Slope & + & + & + & - & - & \\
Stepwise order & 1 & 2 & 3 & & & \\
\hline
\end{tabular}


Table 3. Contributions of independent variables (columns, $X_{1}$ ) to interannual variability observed in dependent variables (rows, $\left.X_{1}\right)$, as annual means. Each $X_{1 j}$ position indicates the cumulative regression coefficient generated from multiple regression analysis of the model shown in that row $\left(\mathrm{X}_{1}\right)$. Overall $\mathrm{r}^{2}$ and $\mathrm{p}$ values for each $\mathrm{X}_{1}$ model are shown in the right column. WL: mean annual water level at Bayou Rigaud; CPUE: catch per unit effort, inshore shrimp; P: annual precipitation; CI: Continental Index weather; TI: Tropical Index weather; MRQ: Mississippi River mean annual discharge; $T$. mean annual temperature

\begin{tabular}{|c|c|c|c|c|c|c|c|}
\hline \multirow[t]{2}{*}{ Dependent variable } & \multicolumn{6}{|c|}{ Independent variables } & \multirow[t]{2}{*}{ Total $r^{2}, p$} \\
\hline & WL & $\mathrm{P}$ & $\mathrm{CI}$ & TI & $\mathrm{MRQ}$ & $\mathrm{T}$ & \\
\hline WL & NA & 0.274 & 0.364 & 0.434 & 0.45 & 0.462 & $\begin{array}{l}0.462 \\
0.034\end{array}$ \\
\hline CPUE & 0.012 & 0.148 & 0.226 & 0.262 & 0.291 & 0.336 & $\begin{array}{l}0.336 \\
0.259\end{array}$ \\
\hline Normalized CPUE & 0.023 & 0.052 & 0.055 & 0.096 & 0.101 & 0.107 & $\begin{array}{l}0.107 \\
0.907\end{array}$ \\
\hline 1 yr lagged CPUE & 0.039 & 0.04 & 0.084 & 0.09 & 0.207 & 0.256 & $\begin{array}{l}0.256 \\
0.471\end{array}$ \\
\hline 1 yr lagged normalized CPUE & 0.084 & 0.211 & 0.236 & 0.237 & 0.27 & 0.278 & $\begin{array}{l}0.278 \\
0.407\end{array}$ \\
\hline
\end{tabular}

sions with either monthly or annual mean coastal water levels here.

Little interannual variability was seen in mean annual temperature, with a 25 yr range of only about $2{ }^{\circ} \mathrm{C}$ (Fig. 4a). Annual precipitation varied considerably, though, with high rainfall observed in 1961, 1966, 1973 to 1975, and 1983 (Fig. 4a). This high local precipitation had a positive effect on water levels in the Barataria Basin estuary (Fig. 3a), probably because the estuary is enclosed on 3 sides by levees (Conner \& Day 1987). These high precipitation years also correspond to a moderate and 2 strong ENSO events, in 1965 , 1972-73, and 1982-83 respectively. Low precipitation in 1987 and 1988 coincided with the low water levels and with the 1987-88 La Niña event.

The weather indices shown in Fig. $4 \mathrm{~b}$ aggregate daily weather by dominant wind direction, with the CI corresponding to northerly winds and the TI to southerly winds (Muller 1977). Higher than average occurrence of $\mathrm{Cl}$ conditions and northerly winds generally leads to decreased water levels in the Barataria Basin estuary as water is forced south to the coast. The opposite happens when TI conditions prevail (Baumann 1987). Prolonged periods of lower CI and higher TI conditions were recorded from 1970 to 1975 and, to a lesser degree, in 1984 to 1986 (Fig. 4b). The 1970 to 1975 predominance by southerly winds corresponded to the period of high coastal water levels from 1972 to 1975 and to the 1972-73 ENSO event (Fig. 3a). Wind patterns during the low water levels of 1987-88, and the La Niña event, did not appear to be particularly anomalous (Fig. 4b)

Mississippi River discharge peaked in 1961, 1973, 1979, and 1983 (Fig. 4c). High river discharges in 1973 and 1983 coincided with high precipitation and with the 1972-73 and 1982-83 ENSO events (Fig. 4a). These
2 events were associated with high precipitation rates both in south Louisiana and in the Mississippi River basin in general. The discharge of unusually large volumes of Mississippi River water to the Louisiana coastal zone has been shown to elevate coastal water levels (Meade \& Emery 1971, Baumann 1987). In fact, the large peaks in Mississippi River output in 1973 and 1983 corresponded with high coastal water levels (Fig. $3 a)$ and the strong (1972-73 and 1982-83 ENSO events. In 1987 and 1988, during the La Niña event which has been related to the North American drought (Kerr 1988, Trenberth et al. 1988) both coastal water levels and Mississippi River discharge were low.

\section{Estuarine inundation regimes and the Louisiana shrimp fishery}

The corrected inshore shrimp catch per unit effort (CPUE, in $\mathrm{kg}$ trip $^{-1}$ ) data showed a significant temporal increase between 1962 and $1988\left(\mathrm{r}^{2}=0.594, \mathrm{p}<0.001\right.$; Fig. 5a) which is directly related to increases in net size and number per boat, as well as increased fishing efficiency, over time (R. Condrey, Louisiana State Univ., pers. comm.). The normalized shrimp CPUEs, after filtering out this temporal increase by computing residual CPUE values from the CPUE vs time regression, are plotted in Fig. 5b. In both cases, several distinctive patterns can be seen. Inshore shrimp CPUE declined markedly in 1972 and remained low for $4 \mathrm{yr}$. CPUE was also low in $1981,1983-84$, and $1986-87$. In 3 of these cases, low harvests of shrimp coincided with ENSO (1972 to 1975 and 1983-84) and La Niña (1987-88) events

The results of multiple and unforced stepwise regression analyses of catch data and environmental parame- 

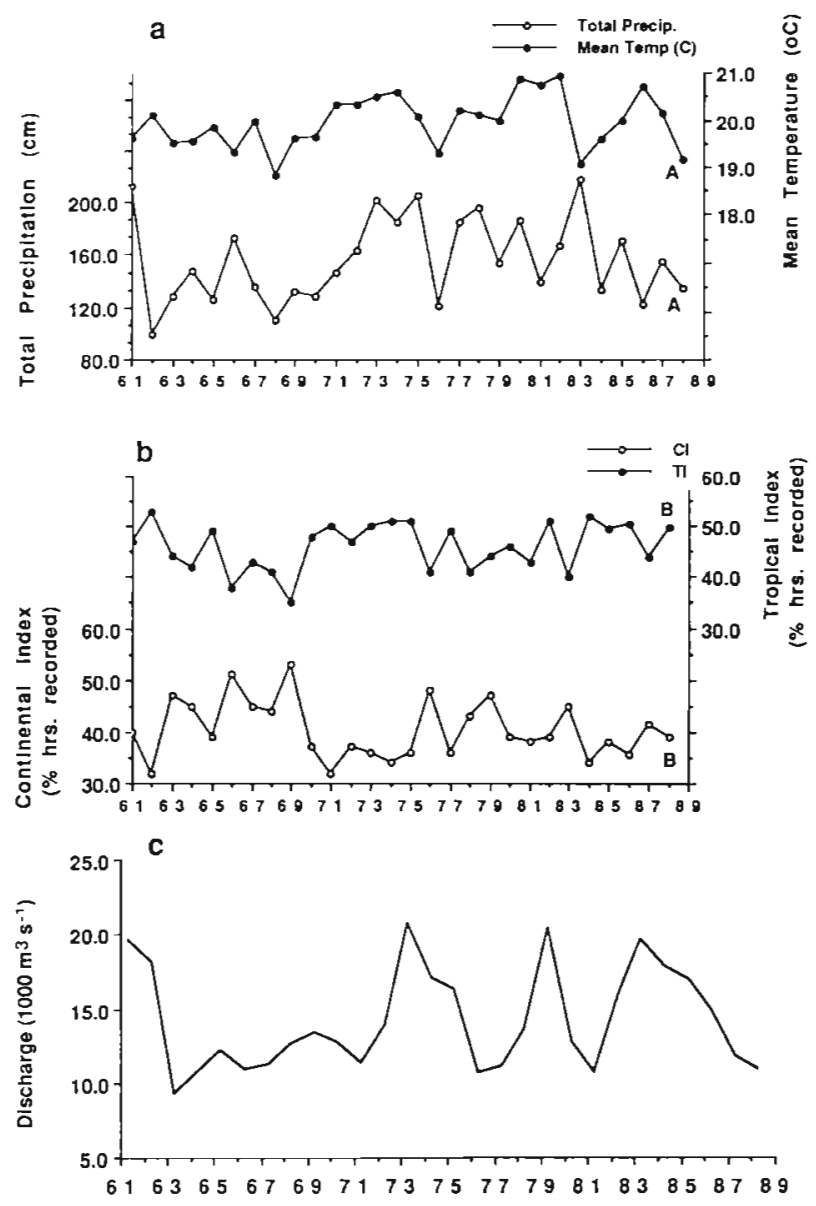

Fig. 4. (a) Mean annual air temperatures and annual precipitation, from daily observations at the New Orleans Moisant Airport (L.O.S.C.). A: Data through July 1988 only. (b) Tropical Index (TI) and Continental Index (CI) weather conditions, from synoptic indices summarizing weather observations at the New Orleans Moisant Airport characterized by southerly and northerly winds, respectively (L.O.S.C.; Muller 1977). B: Data through October 1988 only. (c) Mean annual Mississippi River discharge at Tarbert Landing, based on daily readings (U.S.A.C.E.)

ters are presented in Table 3. The important dependent variables were CPUE, normalized CPUE, 1 yr lag CPUE, and 1 yr lag normalized CPUE. The 1 yr lag CPUE accounted for the possibility that environmental conditions influencing estuarine shrimp populations may not have been manifested until the following yearclass of organisms. In this analysis, we related these dependent variables to annual means of the climatological (precipitation, temperature, wind indices) and hydrologic (Bayou Rigaud water level, Mississippi River discharge) parameters. These annual means were based on only March to October data; monthly catch data were not available. Although none of the multiple regressions were significant at the alpha $=$ 0.05 level, environmental parameters were able to explain $34 \%$ of the variability in uncorrected shrimp

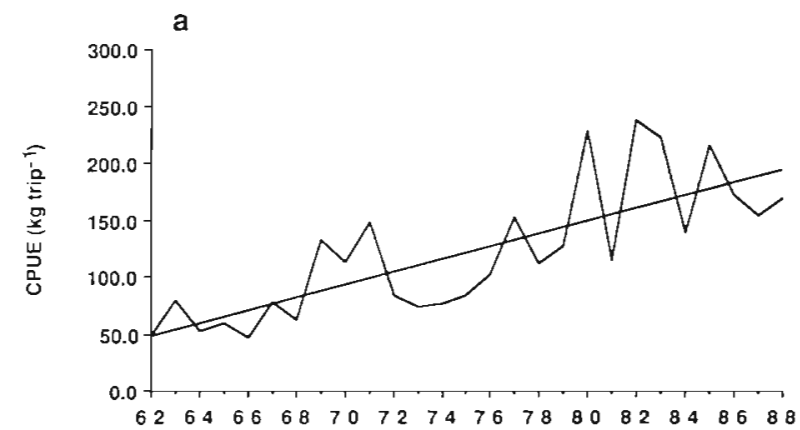

b

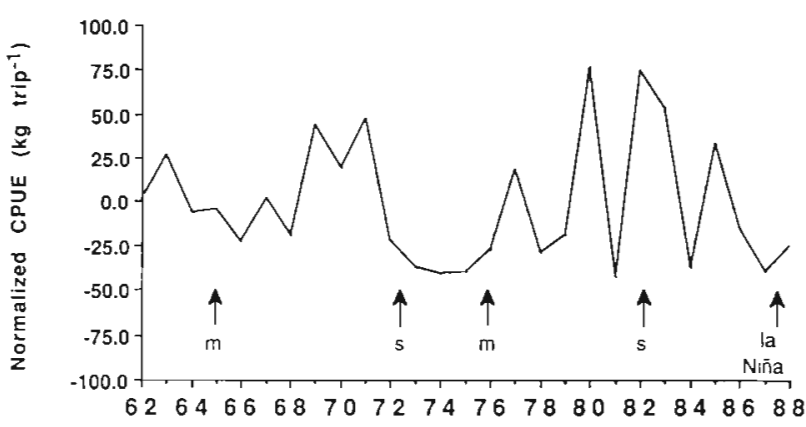

Fig. 5. (a) Inshore shrimp landings for the state of Louisiana, corrected for effort (N.M.F.S.). The significant temporal increase noted by the regression line is described in the text $\left(y=5.797 x-312.098, r^{2}=0.592, p<0.01\right)$. (b) Normalized inshore shrimp catch per unit effort for the state of Louisiana, as residual values from the regression shown in (a). ENSO and La Niña events are indicated with arrows; s: strong event, $\mathrm{m}$ : moderate event

harvest ( $p=0.259$; Table 3 ). In this model, CPUE was negatively related to precipitation, which tends to increase estuarine water levels, and the occurrence of northly winds that tend to lower water levels. This is not surprising because: (1) estuarine shrimp populations have specific salinity requirements and show poor fisheries yields in years with heavy rainfall when estuarine habitat with higher salinity water is restricted (Barrett 1975, Turner 1979, Boesch \& Turner 1984), and (2) juvenile shrimp actively seek food and refuge on estuarine marshes and thus require water levels high enough to flood these marshes (Boesch \& Turner 1984, Zimmerman \& Minello 1984).

Commercial shrimp harvests are affected by a number of such environmental parameters, including water temperature and salinity. Earlier, we suggested that climatologically controlled estuarine flooding regimes are one important regulator of shrimp catch. To test this, we compared each of the 4 measures of shrimp harvest with Bayou Rigaud mean annual water level (March to October water level data) using simple and polynomial regression models and identified a significant second-order polynomial model of Bayou Rigaud mean annual water level and normalized CPUE 


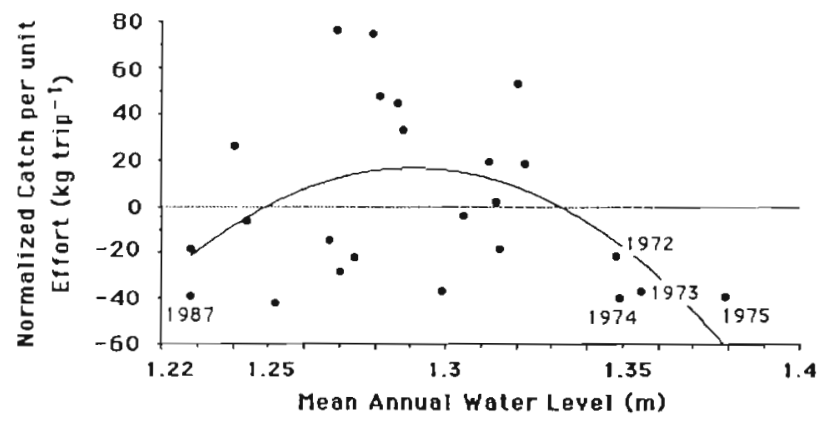

Fig. 6. Relationship between normalized total inshore shrimp catch per unit effort (dependent variable) and mean annual coastal water level at the Bayou Rigaud gauging station (independent variable). Quadratic curve is the line predicted by the significant regression $\left(\mathrm{y}=-16549.6+25673.1 \mathrm{x}-9946.4 \mathrm{x}^{2}\right.$, $\left.\mathrm{r}^{2}=0.259, \mathrm{p}=0.043\right)$. The years indicated correspond to ENSO or La Niña events and/or show unusual climatological conditions, as described in the text. Summarized: $1973=4$ th highest total precipitation in 28 yr data set, highest river discharge in 24 yr data set, \% time under TI (southerly wind) conditions $>28$ yr average in 7 of $12 \mathrm{mo}$. Strong ENSO event. $1975=3$ rd highest total precipitation in $28 \mathrm{yr}$ data set, \% time under TI (southerly wind) conditions $>28$ yr average in 8 of 12 mo. $1987-8=$ low precipitation, lowest water levels. Recent La Niña event

$\left(\mathrm{r}^{2}=0.259, \mathrm{p}=0.043\right)$. Thus, $46 \%$ of the interannual variability in coastal water levels (and marsh inundation) was explained with 5 environmental variables (precipitation, wind indices, Mississippi River discharge, and temperature; Table 3 ) and $26 \%$ of the interannual variability in normalized inshore shrimp harvest data was explained with only coastal water levels (marsh flooding).

This nonlinear relationship between water level and shrimp catch was an interesting result of our analysis (Fig. 6). Shrimp catch per unit effort was highest when water levels were intermediate, and lower when flooding regimes were both low and high. Clearly, however, shrimp harvest cannot be predicted from water levels alone. This was demonstrated in the regression discussed above where $74 \%$ of the interannual variability in inshore shrimp harvest was not associated with water levels and the estuarine flooding regime. We are not attempting to fully explain variability in shrimp catch. Rather, we are using shrimp fishery dynamics, as an available historical measure of estuarine productivity that is dependent on marsh flooding, to demonstrate the ecological importance of climatologically-induced variability in marsh flooding regimes.

As examples of the coincidence of ENSO events and lower shrimp harvests, we note the years associated with a high precipitation ENSO event and the low precipitation La Niña event in Fig. 6. The 4 low harvest points associated with the highest water levels are from 1972 to 1975 and correspond to the 1972-73 ENSO event. While estuarine flooding regimes were high during this 4 yr period, and access to the marsh was (apparently) not hydrologically hindered, local precipitation inputs to the Louisiana coast were also high (Fig. 4a), probably lowering estuarine salinities (Wax 1977). Mississippi River discharge was also very high (Fig. 4c), and a predominance of southerly winds (TI) over northerly winds $\left(\mathrm{Cl}_{i}\right.$ Fig. 4 b) probably facilitated movement of this low salinity Mississippi River input from the nearshore coastal zone into the estuaries, further enhancing the freshening process (Ho \& Barrett 1977. Madden et al. 1988). The lowest combined shrimp harvest and water level, seen in 1987, indicates that the extended period of anomalously low water levels observed during the 1987-88 La Niña event may have had a detrimental effect on inshore shrimp production (Fig. 6). Decreased inundation regimes caused by low water levels, as in 1987-88, probably negatively affect shrimp populations by inhibiting access to vegetated marsh habitat.

\section{SUMMARY AND CONCLUSIONS}

In this paper, we explored the relationship between climatological forcing, water levels on the Louisiana coast, estuarine inundation regimes, and inshore shrimp production. In 1987-88, Louisiana estuaries experienced an extended period of reduced marsh inundation that coincided with a La Niña event Reduced coastal water levels functionally isolated intertidal marshes from the estuary for long periods of time. Multivariate analysis of $25 \mathrm{yr}$ of historical data indicated that wind direction, local precipitation and temperature, and Mississippi River discharge together significantly explained 37 and $46 \%$ of the intermonthly and interannual variability in coastal water levels and marsh inundation, respectively. Further, coastal water levels alone explained a significant $26 \%$ of the observed interannual variability in normalized catch per unit effort data from the Louisiana inshore shrimp fishery. Interestingly, the relationship between water levels (marsh inundation) and shrimp harvest was curvilinear: shrimp catches were low at both low and high coastal water levels while highest shrimp productivity were seen in years with intermediate water levels.

Climatological forcing has direct effects on estuarine flooding regimes in coastal Louisiana, and subsequent effects on estuarine commercial production as measured by inshore shrimp fishery statistics. Thus, there is a direct link between environmental forcing on hydrologic variability and ecological processes dependent on marsh-open water interactions. In this paper, we report for the first time that large-scale ENSO events may have direct ecological effects on SE Gulf 
coast estuaries. Most ENSO events cause higher than average precipitation and coincide with anomalously high water levels. High marsh inundation regimes in these years are associated with large local and remote inputs of fresh water to estuaries. These fresh water inputs probably decrease juvenile shrimp habitat horizontally, as zones of higher salinity waters are spatially reduced, and shrimp harvests decline. The 1987-88 La Niña event, however, caused drought conditions and anomalously low marsh inundation regimes. The effect was a decline in shrimp harvests, probably because juvenile shrimp were denied vertical access to intertidal habitat. The curvilinear relationship between shrimp harvest and estuarine marsh inundation regimes was largely a result of low-catch endpoints and the relationship between local climatological forcing and global ENSO and La Niña events.

Acknowledgements. We thank William Conner, Jay Grimes, Susan Hamilton and Eric Swensen for their assistance with data acquisition and processing, Richard Condrey, James Gosselink, Chris Swarzenski, and Robert Twilley for their helpful discussions, and James Morris, Lawrence Mysak, plus an anonymous revierwer, for their useful reviews of the manuscripts. Field research was made possible by lease-permission granted by Louisiana Land and Exploration. Portions of this research were supported by the National Science Foundation, Grand BSR-A414006.

\section{LITERATURE CITED}

Angell, J. K., Korshover, J. (1987). Variability in U.S. cloudiness and its relation to El Niño. J. Clim. appl. Meteor. 26(5): 580-584

Barnett, T., Graham, N., Cane, M., Zebiak, S., Dolan, S., O'Brien, J., Legler, D. (1988). On the prediction of the El Niño of 1986-7. Science 241. 192-196

Barrett, B. B. (1975). Environmental conditions relative to shrimp production in coastal Louisiana. La. Dept. Wildl. Fish. Tech. Bull 15, p 1-22

Baumann, R. H. (1980). Mechanisms for maintaining marsh elevation in a subsiding environment. M. S. thesis, Louisiana State Univ., Baton Rouge

Baumann, R. H. (1987). Physical variables. In: Conner, W H., Day, J. W. Jr. (eds.) Ecology of the Barataria Basin, Louisiana: an estuarine profile. U.S. Fish Wildl. Serv. Biol. Rep. 85(7.13), p. 8-18

Boesch, D. F., Turner, R. E. (1984). Dependence of fishery species on salt marshes: the role of food and refuge. Estuaries $7(4 \mathrm{~A}): 460-468$

Bowden, W B. (1986). Nitrification, nitrate reduction, and nitrogen immobilization in a tidal fresh-to-brackish marsh sediment. Ecology 67(1): 88-99

Chalmers, A. G., Wiegert, R. G., Wolf, P. L. (1985). Carbon balance in a salt marsh: interactions of diffusive export, tidal deposition, and rainfall-caused erosion. Estuar. coast. Shelf Sci. 21: 757-771

Chen, W. Y. (1983). The climate of spring 1983 - a season with persistent global anomalies associated with El Niño. Mon. Weather Rev. 111: 2371-2384

Cheney, R. E., Miller, L. (1988). Mapping the 1986-7 El Niño with GEOSAT altimeter data. EOS 69 (31): 753-754
Childers, D. L. (1989). Marsh-water column exchanges in the Fourleague Bay estuary. In: Day, J. W., Conner, W H. (eds.) Physical processes, ecological dynamics, and management implications: results of research in the Atchafalaya Bay delta, LA. LSU Seagrant College Programm Report, p. 53-57

Childers, D. L., Day, J. W Jr (1990a). Marsh-water column interactions in two Louisiana estuaries. I. Sediment dynamics. Estuaries (in press)

Childers, D. L., Day, J. W Jr (1990b). Marsh-water column interactions in two Louisiana estuaries. I. Nutrient dynamics. Estuaries (in press)

Chrzanowski, T H., Spurrier, J. D. (1987). Exchange of microbial biomass between a Spartina alterniflora marsh and the adjacent tidal creek. Estuaries 10(2): 118-125

Conner, W., Day, J. W Jr (1987). Ecology of the Barataria Basin, Louisiana: an estuarine profile. U.S. Biol. Rep. 85(7.13). p. $1-164$

Enfield, D. B. (1987). Progress in understanding El Niño. Endeavor 11(4): 197-204

Graham, N. E., White, W. B. (1988). The El Niño cycle: a natural oscillator of the Pacific Ocean-atmospheric system. Science 240: 1293-1302

Hamilton, K. (1988). A detailed examination of the extratropical response to tropical ENSO events. J. Climatol. 8(1): $67-86$

Ho, C. C., Barrett, B. B. (1977). Distribution of nutrients in Louisiana's coastal waters influenced by the Mississippi River Estuar. coast. mar Sci. 5: 173-195

Horel, J. D., Wallace, J. M. (1981). Planetary-scale atmospheric phenomena associated with the Southern Oscillation. Mon. Weather Rev. 109: 813-829

Kerr, R. A. (1988). La Nina's big chill replaces El Niño. Science 241(4869): 1037-8

Kjerfve, B., Greer, J. E., Crout, R. L. (1978). Low-frequency response of estuarine sealevel to non-local forcing. In: Wiley, M. L. (ed.) Estuarine interactions. Academic Press, London, p. 497-513

Lee, $V .(1979)$. Net nitrogen flux between the emergent marsh and tidal waters. M. S. thesis, Univ. Rhode Island

Legendre, L., Demers, S. (1984). Towards dymamic biological oceanography and limnology. Can. J. Fish. aquat Sciences $41: 2-19$

Madden, C. J., Day, J. W. Jr, Randall, J. M. (1988). Freshwater and marine coupling in estuaries of the Mississippi River deltaic plain. Limnol. Oceanogr. 33(4.2): 982-1004

Mather, J. R. (1974). Climatology: fundamentals and applications. McGraw-Hill, New York, N. Y., p. 151-159

McIvor, C. C. Odum, W. E. (1986). The flume net: a quantitative method for sampling fishes and macrocrustaceans on tidal marsh surfaces. Estuaries 9(3): 219-224.

Mclvor, C. C., Odum, W. E. (1988). Food, predation risk, and microhabitat selection in a marsh fish assemblage. Ecology 69(5): 1341-1351

Meade, R. H., Emery, K. O. (1971). Sealevel as affected by river runoff, eastern United States. Science 173: 425-428

Morris, J. T., Kjerfve, B., Dean, J. M. (1990). Dependence of estuarine productivity on mean sea level anomalies. Limnol. Oceanogr (in press)

Muller, R. A. (1977). A synoptic climatology for environmental baseline analysis: New Orleans. J. Appl. Meteor. 16(1): 20-33

Muller, R. A. (1975). Freshwater potential in the Louisiana coastal marshes and estuaries Geoscience and Man 12: $1-7$

Muller, R. A., Faiers, G. E. (1984). A climatic perspective of Louisiana floods during 1982-3. Geosciences Publ., Louisiana State Iniv., Baton Rouge, p. 1-48 
Muller, R. A., Wax, C. L. (1977) A comparative synoptic climatic baseline for coastal Louisiana. GeoSci. Man. 18: 121-129

Muller, R. A., Willis, J. E. (1983). New Orleans weather 1961-1980: a climatology by means of synoptic weather types. Louisiana State Univ. School of Geoscience Misc. Publ. 83-1, Baton Rouge, LA

Mysak, L. A. (1986). El Niño, interannual variability and fisheries in the northeast Pacific Ocean. Can. J. Fish. aquat. Sciences 43: 464-497

Odum, E. P. (1980). The status of three ecosystem-level hypotheses regarding saltmarsh estuaries: Tidal subsidy, outwelling, and detritus-based foodchains. In: Kennedy, V. (ed.) Estuarine perspectives. Academic Press, London, p. $485-495$

Quinn, W. H., Neal, V T., Antunez de Mayolo, S. E. (1987). El Niño occurrences over the past 4.5 centuries. J. Geophys. Res. 92(C13): 14449-14461

Quinn, W H., Zopf, D. O., Short, K. S., Yang, R. T W. K. (1978). Historical trends and statistics of the Southern Oscillation, El Niño, and Indonesian droughts. Fish. Bull. U.S. 76: 663-678

Rasmussen, E. M. Carpenter, T H. (1982). Variations in tropical sea surface temperature and surface wind fields associated with the Southern Oscillation/El Niño. Mon. Weather Rev. 110: 354-384

Sturges, W. Blaha, J. P. (1976). A western boundary current in the Gulf of Mexico. Science 192: 367-369

Thompson, B. A., Forman, W (1987). Nekton. In: Conner, W. H., Day, J. W. Jr (eds.) The ecology of Barataria Basin, CA: an estuarine profile. U.S. Fish Wildl. Serv. Biol. Rep. 85 (7.13): 80-96

Trenberth, K. E., Branstator, G. W., Arkin, P. A. (1988). Origins of the 1988 North American drought, Science 242: $1640-1645$

Turner, R. E. (1987). Tide gage records, geological subsidence, and sedimentation patterns in the Northern Gulf of Mexico marshes. In: Causes of wetland loss in the coastal Gulf of Mexico, Minerals Management Service Report, Vol. 2 p. 203-211

Turner, R. E. (1979). Louisiana's fisheries and changing environemental conditions. In: Day, J. W., Culley, D. D., Turner, R. E., Mumphrey, A. J. Proc. third coastal marsh and estuarine management symposium. Louisiana State Univ., Baton Rouge, p. 363-370

Editor: Dr G. Esser
US Climate Research Committee (1983). El Nino and the Southern Oscillation, a scientific plan. National Academy Press, Washington, D.C.

Wallace, J. M., Gutzler, D. S. (1981). Teleconnections in the geopotential height field during the Northern Hemisphere winter. Mon. Weather Rev. 109: 784-812

Wax, C. L. (1977). An analysis of the relationship between water level fluctuations and climate, coastal Louisiana. Ph. D. Dissertation, Louisiana State Univ., Baton Rouge

Whitaker, R. (1971). Seasonal variations of steric and recorded sealevel of the Gulf of Mexico. Texas A\&M Univ. Ref. 71-14T

Whiting, G. J., McKellar, H. N. Jr, Spurrier, J. D., Wolaver, T. G. (1989). Nitrogen exchange between a portion of vegetated salt marsh and the adjoining creek. Limnol. Oceanogr. 34(2): 463-473

Wolaver, T G., Spurrier, J. D. (1988a). The exchange of phosphorus between a euhaline vegetated marsh and the adjacent tidal creek. Estuar. coast. Shelf Sci. 26: 203-214

Wolaver, T G., Spurrier, J. D. (1988b). Carbon transport between a euhaline vegetated marsh in South Carolina and the adjacent tidal creek. Contributions via tidal inundation, runoff, and seepage. Mar. Ecol. Prog. Ser. 42: $53-62$

Wolaver, T. G., Wetzel, R. L., Zieman, C. J., Webb, K. L. (1980). Nutrient interactions between salt marsh, mudflats, and estuarine water In: Kennedy, V S. (ed.) Estuarine perspectives, Academic Press, London, p. $123-133$

Wolaver, T G., Zieman, J. C. (1983a). Tidal exchange of nitrogen and phosphorus between a mesohaline vegetated marsh and the surrounding estuary in the Lower Chesapeake Bay. Estuar. coast. Shelf Sci. 16: 321-332

Wolaver, T G., Zieman, J. C. (1983b). Effect of water column, sediment, and time over the tidal cycle on the chemical composition of tidal water in a mesohaline marsh. Mar. Ecol. Prog. Ser 12: 123-130

Yarnal, B. (1985). Extratropical teleconnections with El Nino/Southern Oscillation (ENSO) events. Prog. Phys. Geogr. 9: 315-352

Zimmerman, R. J., Minello, T. J. (1984). Densities of Penaeus aztecus, Penaues setiferus, and other natant macrofauna in a Texas saltmarsh. Estuaries 7(4A): $421-433$

Manuscript first received: Novernber 28, 1989

Revised version accepted: May 23, 1990 